\title{
A ESPACIALIDADE DA COVID-19 E O PANDEMÔNIO EM MEIO A PANDEMIA NAS COMUNIDADES TRADICIONAIS DA CAJAÍBA - PARATY
}

\author{
The spatiality of COVID-19 and the pandemonium amid the pandemic in \\ traditional communities of Cajaíba - Paraty
}

\author{
Abbul Mahmebb Said - José Carlos da Silva ${ }^{1}$ \\ Doutorando do Programa do PPGHS/FFP/UERJ \\ abbulsaid@yahoo.com.br
}

Artigo enviado para publicação em 03/05/2020 e aceito em 04/05/2020

DOI: $10.12957 /$ tamoios.2020.50678

\begin{abstract}
Resumo
A nova pandemia que se agrava na atualidade coloca em xeque as formas de ocupação do espaço, os padrões de consumo e o próprio modelo de produção e exploração do meio ambiente. Apesar das multivariáveis que envolvem a questão do surgimento da pandemia, o vírus vem se espalhando pelos mercados financeiros da economia global e nos mercados locais. As interações espaciais globais orientadas pelas verticalidades em detrimento das horizontalidades tencionam e desorientam as ordens e desordens que chegam aos lugares, geram incertezas na implementação de políticas públicas de inclusão das camadas mais vulneráveis socialmente diante do espraiamento espacial do novo coronavírus, principalmente em redutos mais isolados como Paraty-RJ, onde se encontram instaladas comunidades tradicionais pesqueiras em lugares de difícil acesso. Em se tratando da chegada do vírus em Paraty, a pandemia já causa pandemônio entre as comunidades costeiras e com o aviltamento nos preços do principal meio de subsistência dessas famílias, o cenário que se apresenta é o de aprofundamento da crise sanitária e social nessas comunidades. O objetivo deste ensaio é analisar o contexto do Coronavirus e sua expansão mundial e discutir os impactos desse contexto nas comunidades tradicionais caiçaras e pesqueiras de Cajaíba (Paraty) e analisar suas consequências na pesca artesanal e nos modos de vida.
\end{abstract}

Palavras-chave: Mobilidade espacial; pesca artesanal; políticas públicas; Cajaíba; COVID-19.

\begin{abstract}
The new pandemic that is getting worse nowadays calls into question the forms of occupation of space, consumption patterns and the very model of production and exploration of the environment. Despite the multivariables that involve the question of the emergence of the pandemic, the virus has spread to financial markets in the global economy and local markets. Global spatial interactions oriented by verticalities to the detriment of horizontalities intend and disorient the orders and disorders that arrive at places, generate uncertainties in the implementation of public policies for the inclusion of the most socially vulnerable strata in view of the spatial spread of the new coronavirus, especially in more isolated strongholds such as Paraty-RJ, where traditional fishing communities are installed in places that are difficult to access. When it comes to the arrival of the virus in Paraty, the pandemic is already causing pandemonium among coastal communities and with the degradation in prices of the main means of subsistence for these families, the scenario presented is that of deepening the health and social crisis in these communities. The objective of this essay is to analyze the context of the Coronavirus and its worldwide expansion and to discuss the impacts of this context on the traditional caiçaras and fishing communities of Cajaíba (Paraty) and to analyze its consequences in artisanal fishing and in the ways of life.
\end{abstract}

Keywords: Spatial mobility, artisanal fishing, public politics, Cajaíba, COVID-19. 


\section{Introdução}

A principal pauta que vem movimentando os últimos meses estão sendo os efeitos devastadores do coronavírus, causador da SARS-CoV-2 batizada de COVID-19 como nova doença epidêmica na área da saúde pública e interfere nas tendências do mercado aprofundando a crise do capitalismo (mais uma vez), os reflexos apontam para um aprofundamento da crise econômica, com evidente potencial de desarticulação das cadeias produtivas em nível global. Diante desse novo cenário mundial é preciso reconhecer a necessária reflexão sobre construção da ciência do século XXI e a nova pandemia que se agrava na atualidade deve orientar a reflexão crítica sobre as formas de ocupação do espaço, padrões de consumo e o próprio modelo de produção e exploração do ambiente de acordo com algumas análises que vem sendo explicitadas em meio ao pandemônio político-econômico-social que a pandemia estabeleceu. No Brasil, o desmonte das políticas relacionadas à segurança alimentar colocam em risco o acesso à alimentação saudável para a maioria dos trabalhadores, em especial às camadas mais empobrecidas e invisibilizadas da população.

No entanto, apesar da crise que se agrava, o governo federal brasileiro, na pessoa do próprio presidente da República, segue levando a cabo um conjunto de políticas com potencial de aprofundar a crise econômica, social e ambiental pela qual passamos ao ir na contramão das orientações estabelecidas pela Organização Mundial da Saúde, suscitando a manutenção das atividades comerciais em detrimento do isolamento social das famílias. Soma-se a isso as pressões exercidas por alguns setores da extrema direita impulsionados por empresários pelo fim imediato do isolamento social e a reabertura do comércio que combina a facilitação da disseminação da COVID-19 com a ampliação dos efeitos do desemprego e da pobreza, situação que parece visar a criação das condições de caos social propícias para a ruptura institucional autoritária iminentes desde a posse do atual presidente da república e tão ambicionada por alguns setores da ala direitista do país.

A crise social, política e econômica que se avizinha permite uma série de análises comparativas com crise de 2008 ou tantas outras já ocorridas no mundo. Diferente da crise de 2008, essa nova pandemia se origina no mercado tradicional chinês e se espalha pelos mercados financeiros e a particularidade do momento atual é a possibilidade de questionar as fragilidades de uma ordem capitalista globalizada a partir do coronavírus. Esse questionamento se apresenta de forma iminente, pois a interdependência imposta pelas cadeias globais de produção de valor, em prol de uma maior especialização e eficiência do mercado financeiro, oculta uma imensa vulnerabilidade para empresas e nações, estas cada vez mais conectadas via interação espacial global como asseveram Sposito \& Guimarães $(2020)^{2}$.

Outro agravante relacionado a essa interação espacial global são as aglomerações urbanas nos grandes centros, campo fértil para a propagação do vírus. Dos pontos de destaque da nota técnica da ENSP/Fiocruz $(2020)^{3}$, são averbados que há muitos desafios para comportar a demanda por cuidados em centros de maior aglomeração populacional, onde já são maiores os números de casos da COVID-19 e a estrutura então disponível não comportará a já crescente demanda considerando a rápida propagação do vírus. A nota técnica da ENSP/Fiocruz indica ainda que frente a um quadro epidêmico já instalado, é fundamental monitorar a elevada probabilidade de que a demanda pelos recursos disponíveis cresça de forma exponencial e com padrões de usos prolongados.

$\mathrm{Na}$ outra frente de combate estão as análises e especulações sobre a origem do vírus, segundo cientistas sociais, médicos sanitaristas e a acadêmicos por meio de pesquisas nas universidades e ciclos de debates especulam sobre a origem da COVID-19 de modo que, de forma mais específica (na área das ciências biológicas e 
epidemiológicas), possam ser sequenciados o DNA do vírus e novos estudos possam ser desenvolvidos para a compreensão da estrutura molecular do mesmo de modo que medicamentos ou alguma vacina possam ser desenvolvidos a curto e médio prazo. Nesse momento tão crucial todos precisamos de respostas científicas rápidas, mas as políticas de acumulação capitalista e de desestabilização de investimentos na área da ciência culminaram na desaceleração de muitas pesquisas pelo país. $\mathrm{O}$ que todos parecem concordar é que a estrutura capitalista que o mundo vive atualmente em busca de acumulação sem precedentes explorando de forma demasiada os recursos naturais, favorece a desordem ambiental enfrentada pela natureza na tentativa de sua dominação plena, o que gera desequilíbrio ambiental e consequentemente distúrbios como o surgimento dessa nova pandemia que coloca em risco essa frágil estrutura financeirizada de base densamente técnica e informacional.

Orientados pelas conjecturas dos analistas/especialistas sobre a fragilidade do sistema financeiro e suas empresas vulneráveis às crises de diversas matizes, Escobar $(2020)^{4}$ traz para o conjunto das discussões importantes análises de cunho geopolítico enfatizando a vulnerabilidade desse sistema vigente, marcado pela força da dominação caracterizada pela racionalidade técnica, política e econômica, frente ao crescimento das curvas de expansão da pandemia (Alves, 2020). O pandemônio instalado em meio a pandemia do novo coronavírus já vem colocando em xeque a economia global e incrementando de forma inesperada, fortes possibilidades de desestabilização e desarticulação de cooperações comerciais entre países emergentes como a China e o Brasil por exemplo, dadas as últimas reviravoltas políticas e diplomáticas entre essas duas economias como demonstra Yang $(2020)^{5} \mathrm{em}$ análise sobre a conjuntura e evidências em relação ao surgimento do vírus e as notícias propagadas a respeito do mesmo, inclusive algumas veiculadas de forma leviana pelo próprio filho do presidente da república do Brasil.

Outras vertentes de estudos, como as ciências biológicas, também especulam sobre a origem da COVID-19 como averbam Andersen et al (2020) ${ }^{6}$. Com a iminência de espraiamento do vírus na configuração espacial da América Latina, o Brasil se tornou o novo ponto de expansão do mesmo e a título de recorte espacial deste ensaio, Paraty no estado do Rio de Janeiro anuncia medidas de proteção e implementação de políticas públicas de inclusão das famílias mais vulneráveis diante da espacialização. Ainda sobre a configuração do espaço e suas formas de espacialidade Santos (2017) ${ }^{7}$ averba as relações analíticas entre as verticalidades e as horizontalidades que impõe ordens e desordens no lugar como assevera Ribeiro $(2005)^{8}$.

Com o ordenamento espacial vertical, as cidades convivem de forma intensa com os impulsos globais e o município de Paraty (RJ) não é diferente. As ordens e desordens que chegam aos lugares alteram as dinâmicas socioeconômicas dos sujeitos invisibilizados que assistem impossibilitados de agir de forma contrária ao aviltamento de preços de seu principal produto de subsistência pautado na pesca artesanal. Nesse sentido, as formas de solidariedade, sociabilidade e as geograficidades (DARDEL, 2011) ${ }^{9}$ dos sujeitos sofrem tensionamentos frente aos ditames exógenos que verticalmente atingem seus lugares e portanto, suas atividades de pesca. Ao mesmo tempo a pesca acaba por geograficizar os lugares e entra no circuito espacial do comércio de pescado como explicita Said-Silva (2019) ${ }^{10}$, mas tendo em vista o processo de aviltamento do valor do pescado em função da pandemia, teme-se pelo aprofundamento da invisibilidade dos sujeitos e a dificuldade das políticas públicas atingirem essas comunidades que são as mais necessitadas de serem assistidas nesse momento.

Afinal, como justifica Silva $(2015)^{11}$, "pensar em políticas públicas para a pesca artesanal é um grande desafio". No entanto, não podemos deixar continuar invisíveis a 
fragilidade e vulnerabilidade das camadas mais empobrecidas e espoliadas da sociedade. É preciso a implementação das políticas públicas nessas camadas sociais de forma impreterivelmente urgente nesses tempos tão sombrios do presente. Assim como as formas de domínio econômico se espraiam pelo mundo, dessa vez também um vírus invisível acompanha esse espraiamento apoiado na dinâmica espacial dos mercados e da mobilidade urbana crescente no mundo todo, o que por si só já justifica a real necessidade de implementação das políticas inclusivas e protecionistas para assegurar a saúde e alimentação dos sujeitos.

Haja vista que, de forma muito rápida e inesperada, também as formas de espacialidade do novo vírus vêm agravando as grandes conexões de mercado que estão se rompendo pelo impacto da pandemia na Ásia e na Europa, e mais recentemente na América Latina. Imaginem esse mesmo impacto nas sociedades mais vulneráveis do planeta. Como consequência dessa pandemia, viagens internacionais estão sendo limitadas com o fechamento de fronteiras aéreas, terrestres e marinhas, e dessa forma, medidas protecionistas estão sendo tomadas principalmente em relação a produtos e equipamentos médicos, com a proibição de exportação de máscaras e respiradores segundo pudemos acompanhar nos noticiários televisivos das últimas semanas.

Diante deste cenário a FAO aponta para o risco de tensões no sistema alimentar mundial devido a pandemia que adquire uma espacialidade geográfica como nunca visto. Admitem os analistas/especialistas nos meios jornalísticos/televisivos que os impactos podem ocorrer nos sistemas de logística, oferta de força de trabalho e queda da demanda. Assim, a preocupação com a crise provocada pelo novo coronavírus é a possibilidade de ela afetar as cadeias globais de suprimentos e medicamentos. Também, as restrições no comércio podem provocar rupturas nas cadeias de abastecimento de alimentos e outros serviços. No caso do Brasil, há especulações que indicam o desmonte das políticas públicas relacionadas à segurança alimentar, que começaram a ser desarticuladas desde o governo de Michel Temer somada ao aprofundamento da crise pelo novo coronavírus, e a destruição dos mecanismos de garantia de preços mínimos e de estoques públicos de alimentos, podem levar à crise de abastecimento de alimentos no país.

Nota-se de imediato que são muitas as variáveis que envolvem a questão da pandemia e que vem colocando o mundo em verdadeiros alvoroço e pandemônio, principalmente em função da multiescalaridade do mercado financeiro mundial que possui ramificações espacializadas por todos os quadrantes do planeta. E assim como o mercado, também o vírus vem ganhando as dimensões espaciais do planeta seguindo por essas ramificações espacializadas do próprio mercado e suas conexões com todos os quadrantes geográficos do planeta. Assim sendo, a maior preocupação das grandes economias capitalistas pautadas na racionalidade técnica e informacional está sendo justamente tentar de alguma forma salvar seus negócios pelo mundo, o que leva seus dirigentes a entrarem em grandes embates/debates sobre qual caminho seguir em tempos de crise onde o inimigo é invisível e imprevisível. Nos grandes centros urbanos de aglomeração de pessoas e de capitais o tema muito debatido nas últimas semanas se pauta pelo grande dilema: risco de contrair o vírus $x$ prejuízo financeiro.

A invisibilidade do vírus e sua imprevisibilidade de ação faz com que seus efeitos podem aparecer a qualquer momento e multidões são pegas de surpresa como se o inimigo estivesse de espreita aguardando o momento de atacar. É essa a sensação dos sujeitos nas ruas e um sentimento de incertezas e obscuridade vai tomando vulto nas grandes metrópoles chegando até recantos mais isolados dos centros urbanos como as comunidades tradicionais. Diante desta realidade catastrófica do tempo presente, assistimos a um processo de aprofundamento de uma crise que vai muito mais além de qualquer outra crise financeira como as inúmeras e intrínsecas crises cíclicas do 
capitalismo, pois evidentemente estamos assistindo a uma crise de saúde pública global que vem afetando demasiadamente o mercado mundial capitalista.

Sobre essa questão de crise humanitária Santos (2020) infere no início de seu novo trabalho $^{12}$ que "a atual pandemia não é uma situação de crise claramente contraposta a uma situação de normalidade" e que em função das políticas neoliberais que o mundo vem imprimindo em sua construção cada vez mais subordinada ao sistema financeiro, "o mundo tem vivido em permanente estado de crise" (SANTOS, 2020, p. 5). O autor esclarece que em processo de crise há os indicativos de que crises são passageiras e há o processo de crise que se estende por décadas e esta não tem previsão de melhoras ou superação, pois na verdade "o objetivo da crise permanente é não ser resolvida". Essa é uma situação que o mundo vive a quarenta anos segundo o autor e que o modelo econômico capitalista se utiliza para manter o estado de crise permanente de modo que as políticas neoliberais possam continuar sendo impostas e inclusive justificadas por esse estado de crise até pelas camadas mais populares da sociedade.

Em relação ao novo coronavírus, o autor infere que "a pandemia vem apenas agravar uma situação de crise que a população mundial tem vindo a ser sujeita" (SANTOS, 2020, p. 6). Os geógrafos Sposito \& Guimarães (2020) inferem que dadas essas condições impostas pelo mundo em que vivemos, estamos diante de uma pandemia inusitada. Considerando a importância dessas assertivas e apesar da realidade da pandemia exigir urgências na produção e propagação de informações temos que tomar cuidado com as especulações que já proliferam a cada dia sendo muitas levianas e ardilosas espalhadas em forma das chamadas Fake News. Estas desorientam o imaginário social, principalmente daquela camada social menos abastada e com déficit educacional que historicamente são exploradas pelo capital monopolista e suas retóricas alienadoras da realidade social e econômica mundial.

Embora o mundo esteja globalizado, portanto, conectado e as informações circulem com maior rapidez, também as Fake news acompanham esse movimento rápido de difusão de informações falsas que possuem como única intenção confundir os espíritos. E na rabeira dessa dinâmica informacional, portanto, da densidade técnica aliada ao movimento e fluidez da mobilidade social o vírus também adquire velocidade em sua espacialização pelo planeta. Porém, nota-se, infelizmente, que grandes camadas da sociedade ainda não estão entendendo o problema de crescimento do número de infectados pelo novo coronavírus, apesar do grande fluxo de informações correntes e dos fatos ocorridos na China, Itália, Espanha, EUA e agora de forma exponencial também na América Latina e consequentemente no Brasil.

As análises do presente artigo apontam para um cenário caótico e de verdadeiro pandemônio em meio a pandemia da COVID-19. Assim, as especulações sobre a COVID19 e a realidade dos lugares invisibilizados são questões de difícil elucidação em momento tão crítico e exigem das autoridades um profundo debate sobre os rumos que o mundo pode vir a seguir na hipótese dessa pandemia se alastrar por todos os recantos do planeta e aprofundar os problemas sociais das camadas mais vulneráveis, invisibilizando ainda mais as zonas opacas do planeta. Em função do exposto, o objetivo deste ensaio é discutir a espacialidade da COVID-19 nesses espaços de invisibilidade onde se encontram as comunidades tradicionais caiçaras e pesqueiras de Cajaíba e analisar suas consequências na pesca artesanal e nos modos de vida das mesmas, historicamente com alto grau de vulnerabilidade econômica e social. 


\section{As especulações sobre a COVID-19 e a realidade dos lugares invisibilizados}

Informa Boaventura de Sousa Santos (2020, p. 8), que segundo a Organização Mundial de Saúde, a origem do vírus ainda não está determinada e as especulações insinuam a China como foco inicial da pandemia. No entanto, autores como Pepe Escobar faz uma análise geopolítica da situação econômica no mundo e aponta sinais de evidência da origem do vírus como tendo sido manipulado em laboratório dos EUA. Da mesma forma, o Cônsul chinês no Rio de Janeiro, Li Yang, em resposta às provocações do Deputado Eduardo Bolsonaro, um dos filhos do atual dirigente do país, assevera que há fortes evidências do vírus ter sido manipulado nos EUA, mas admite que ainda está por confirmar efetivamente a origem do vírus e embora o surto da COVID-19 tenha se dado primeiramente em Wuhan, na China, não significa necessariamente que Wuhan foi a fonte inquestionável do novo coronavírus. Nessa resposta às provocações, Li Yang indica ainda que

“[...] o diretor do Centro de Controle e Prevenção de Doenças dos Estados Unidos já reconheceu que, durante a chamada 'epidemia de gripe' nos Estados Unidos, no ano passado (2019), algumas pessoas teriam morrido por COVID19. Isso justifica que, muito provavelmente, os Estados Unidos foram a fonte da COVID-19" (YANG, 2020, s/p. - Grifo nosso).

Apesar dessa assertiva bastante comprometedora em relação ao diretor acima referido, tanto o Cônsul chinês como Pepe Escobar se mantêm no campo das evidências e Escobar afirma que "independentemente de sua origem, que ainda não está estabelecida de maneira conclusiva, [...] a COVID-19 já coloca questões imensamente sérias sobre biopolítica e bioterrorismo". Pepe ainda infere que "a hipótese de trabalho do coronavírus como uma arma biológica muito poderosa, mas não provocadora do Armagedom, a revela como um veículo perfeito para o controle social generalizado em escala global". Como vemos, as especulações e conjecturas sobre o vírus vão muito além da crise de saúde global, perpassando por questões geopolíticas, pelos grandes mercados e pela economia global e suas ramificações, agora correndo sérios e previsíveis riscos de enxugamento da máquina capitalista que move o mundo. Escobar assevera que "ainda estamos apenas começando a entender as consequências da COVID-19 para o futuro do turbo-capitalismo neoliberal. $\mathrm{O}$ certo é que toda a economia global foi atingida por um disjuntor insidioso, literalmente invisível".

Como se percebe pelas análises, a economia global em face do pandemônio em meio a atual pandemia corre sérios riscos e o espectro do vírus atormenta sobremaneira as elites imperiais e seu poderio hegemonizado em todos os quadrantes do planeta. Apesar da rica discussão que suscita essas análises, assertivas e considerações a respeito da interferência do vírus na economia global, por ora não aprofundaremos essa questão de caráter geopolítico e econômico na esfera mundial, pois não é objetivo deste ensaio, cumprindo reiterar que o objetivo se pauta em direcionar esses aspectos mais próximos das comunidades tradicionais caiçaras de Cajaíba. Além disso, também analisando outras vertentes sobre a origem da COVID-19, outras evidências destacam que o vírus foi e continua sofrendo mutações no meio natural e pode ter tido origem em qualquer parte do planeta, como infere Andersen, Rambaut e Garry (2020) em artigo publicado pela Nature Medicine em 17 de março de 2020. Informam os autores que

\footnotetext{
"Desde os primeiros relatos de uma nova pneumonia (COVID-19) em Wuhan, província de Hubei, China, houve uma discussão considerável sobre a origem do vírus causador, SARS-CoV-2 (também conhecido como HCoV-19). As infecções por SARS-CoV-2 estão agora disseminadas e, em 11 de março de
} 
2020, 121.564 casos foram confirmados em mais de 110 países, com 4.373 mortes" (ANDERSEN, et al., 2020, s/p.).

De acordo com os autores, já existem diversos vírus corona, sendo este SARSCoV-2 o sétimo coronavírus (batizado de COVID-19) conhecido por infectar seres humanos e, em relação a esse novo coronavírus, dado o nível de variação genética no pico, é provável que vírus do tipo SARS-CoV-2 sejam descobertos em outras espécies. Nesse caso, concordam os autores entre si e inferem que o processo de mutação do tipo SARS-CoV-2 ainda é desconhecida da ciência e será importante determinar seu impacto na transmissibilidade e patogênese em modelos animais. Os autores em um primeiro momento afirmam que o vírus não poderia ter sido manipulado em laboratório, no entanto, no decorrer da análise inferem que

\footnotetext{
"Pesquisas básicas envolvendo a passagem de coronavírus tipo SARS-CoV de morcego em cultura de células e/ou modelos de animais estão em andamento há muitos anos em laboratórios de nível 2 de biossegurança em todo o mundo, e existem casos documentados de fugas laboratoriais de SARS-CoV. Portanto, devemos examinar a possibilidade de uma liberação laboratorial inadvertida do SARS-CoV-2" (ANDERSEN, et al, 2020, s/p.).
}

Pelas discussões em tela, está presente de forma contundente muitas variáveis envolvendo o possível surgimento do novo coronavírus e por enquanto qualquer tentativa de elucidar a questão de forma mais expressiva e conclusiva, permanece no campo das evidências, portanto, de especulações diversas. Não faz parte de nossa análise buscar as evidências em debate no mundo sobre as possibilidades reais de origem do vírus nesse momento. Apontamos as evidências acima a título de situar as diversas discussões que envolvem o vírus e sua origem, bastando sabermos então que segundo os autores existem alguns tipos de coronavírus, cada qual com sua especificidade e área de abrangência (tipos de animais infectados que não o homem). Mas esse tipo do qual estamos a versar ainda suscita inúmeras dúvidas e vem causando transtornos e insegurança pelo mundo, principalmente pelo fato do vírus se encontrar atualmente em múltiplas escalas espaciais colocando em xeque o modelo capitalista imperialista então presente no mundo.

No entanto, suscitamos o debate sobre as evidências relacionadas ao surgimento do vírus para melhor compreensão de sua possível trajetória inicial, para daí em diante analisarmos sua espacialidade, visto que seu espraiamento geográfico coloca em xeque a economia global. Outro fator que coloca em xeque o modelo capitalista de produção desenfreada e o processo de urbanidade que atualmente rege o mundo são as aglomerações humanas em todos os quadrantes espaciais do planeta e a busca cada vez maior da mobilidade urbana. Sobre a questão da aglomeração urbana a nota técnica da ESNP/Fiocruz reitera que "há muitos desafios para comportar a demanda por cuidados em centros de maior aglomeração populacional, onde já são maiores os números de casos de COVID-19, mas também se situam mais recursos" (ESNP/Fiocruz, 2020, p. 7).

Mas não necessariamente a concentração de maiores recursos significa a distribuição equitativa dos mesmos para todas as camadas sociais da população. Além disso, com a rápida expansão do vírus sobre todos os quadrantes coloca em risco o sistema de saúde que já opera com baixa capacidade de atendimento ao público em geral. E no caso de uma pandemia dessa natureza, quanto mais as pessoas circularem, maior será a difusão do vírus pelas metrópoles. Portanto, assim como o grande fluxo de mercadorias que circulam diariamente pelos quadrantes espaciais, também as pessoas transitam cada vez mais em grandes fluxos urbanos, seja por mobilidade pendular, busca de serviços oferecidos nos grandes centros comerciais ou longas viagens a lazer ou negócios. A rede urbana vai se tornando cada vez mais ramificada e a mobilidade pendular pode ser 
considerada uma das maiores ameaças a população mais pobre, pois é essa camada social que se vê obrigada a enfrentar os meios de transportes diariamente atravessando a cidade em trens, metrôs, ônibus e outros meios disputando cada centímetro desses veículos dadas as condições dos serviços oferecidos pelas empresas sem o devido acompanhamento dos órgãos públicos de gestão e físcalização do setor de transporte urbano.

Tendo em vista o alto grau de conectividade do mundo financeiro e de produção capitalista, agora ameaçado pela pandemia instalada, e a questão da espacialidade do vírus facilitada justamente por essa conectividade em conjunto com a mobilidade espacial planetária, mesmo a contragosto das instituições financeiras os dirigentes da Organização Mundial da Saúde sugerem o isolamento social das famílias como meio de frear esse espraiamento do vírus. Também a nota técnica da ESNP/Fiocruz destaca essa necessidade inferindo que "as medidas para minimizar a circulação de pessoas continuarão sendo centrais para diminuir os níveis de transmissão da COVID-19 e evitar colapso do sistema de saúde" (ESNP/Fiocruz, 2020, p. 2).

Assim, aglomerações urbanas, a mobilidade espacializada e o isolamento social necessário diante do alto grau de transmissibilidade do vírus se tornaram um componente desafiador para o sistema capitalista mundial pautado na financeirização da vida. Como assevera Escobar (2020), as consequências da COVID-19 para o futuro do turbocapitalismo neoliberal podem ser desastrosas e coloca o mundo em busca de alternativas em meio ao caos econômico que ronda a economia global. Em casos como esse de pandemia, as aglomerações urbanas acometem toda a população, pois é nesse meio que o vírus encontra as condições ideais e extremamente férteis para se alastrar, aumentando sobremaneira o grau de transmissibilidade, generalizando ainda mais o pandemônio em meio a pandemia de uma situação já caótica em termos de organização social voltada a produção e consumo desenfreado de mercadorias, bens e serviços.

\section{Aglomerações urbanas, a mobilidade espacializada e o isolamento social necessário diante do alto grau de transmissibilidade do vírus}

Como já repetido diariamente nos grandes meios televisivos e nos principais jornais do mundo, vivemos uma crise de saúde global como nunca antes visto. Segundo as apurações de algumas análises, o processo de globalização permitiu a espacialização de mercados, pessoas e informações, o que favorece de maneira igualmente favorável a expansão/difusão do novo coronavírus pelo planeta de forma tão rápida e eficaz que quase não houve tempo de articular políticas de protecionismo no conjunto de países afetados pela pandemia. Verdadeiro alvoroço e pandemônio em meio a pandemia está sendo repercutido pelo planeta sem que os grandes líderes mundiais possam se antecipar ao processo de expansão e difusão do novo vírus. Nos países afetados mais drasticamente pelo novo vírus ainda estão sendo realizadas tentativas de controle de expansão do mesmo enquanto grande parte da humanidade vai se infectando. A velocidade com que o vírus se propaga não dá tempo aos setores de saúde mundial se prepararem com certa antecedência para combater tal propagação, muito disso atribuído às políticas de privatização dos serviços de saúde e diminuição do papel do Estado para atender o mercado financeiro mundial comandado pelas grandes economias globais.

Em se tratando de grandes economias globais que foram afetadas pelo novo coronavírus, a China, um dos primeiros países até então afetados pela pandemia, acionou métodos de repressão e de vigilância particularmente rigorosos para tentar controlar eficazmente a pandemia, situação diferente na Itália em um primeiro momento, o que facilitou o replicamento bastante expressivo do número de infectados e o grande número de óbitos divulgados. Na sequência, outros países também tiveram suas economias 
abaladas e entraram na lista de países afetados pela crise de saúde propagada pelo novo coronavírus como ocorreu na Espanha dizimando boa parte da população infectada, depois nos EUA e mais recentemente vem ocorrendo por todo o planeta atingindo também a América Latina. A Itália iniciou o processo de controle mais eficaz um pouco tarde demais e pagou caro pela decisão tardia, pois no início da pandemia o país estava mais preocupado em salvaguardar as transações do mercado financeiro. $O$ país pagou um preço alto demais por subestimar o novo vírus, o sistema de saúde entrou em colapso e segundo as apurações jornalísticas houveram momentos trágicos de tomadas de decisões sobre quem deveria viver ou morrer enquanto a pandemia se alastrava pelo país.

Grande alastramento também se deu nos EUA e estados como Nova Iorque vem batendo recordes de infectados. No Brasil estamos caminhando na mesma direção da Itália, Espanha e Estados Unidos e a população parece não se dar conta da realidade mundial em termos de pandemia e o pandemônio que essa crise sanitária vem causando no mundo parece não afetar o povo brasileiro por completo apesar do terror anunciado diariamente nas redes jornalísticas nacional. Essa assertiva corresponde as diversas informações que chegam diariamente pelas redes sociais de que as pessoas continuam circulando de forma demasiadamente desnecessária pelos grandes centros, salvo aqueles que de fato ainda não conseguiram uma forma de permanecerem em quarentena e são obrigados a continuarem trabalhando, portanto, circulando em meio ao caos anunciado.

Considerando que quanto maior a circulação de pessoas e mercadorias, mais o vírus tem possibilidade de se movimentar e ir se espalhando para todos os quadrantes espaciais do país, somos da mesma opinião de Sposito \& Guimarães (2020) que atribuem essa expansão do vírus em contextos metropolitanos muito em função da espacialidade de tudo e de todos em um mundo globalizado. As análises dos autores sobre a questão da difusão da COVID-19 no país indicam que essa difusão segue um modelo relacionado a interações espaciais na rede urbana. Querem os autores inferirem que a propagação do vírus está relacionada a espacialidade embora reconhecem que são muitas variáveis e fatores incidindo sobre o processo e que nesse momento de pandemia e pandemônio generalizado é preciso a busca de múltiplos saberes e áreas do conhecimento para melhor reflexão sobre a lógica de difusão do vírus e suas possíveis consequências.

Também é preciso frisar e mais uma vez concordar com os autores que essa pandemia não se trata apenas de um problema de saúde pública como já ocorrido em outras pandemias mundiais como os vários tipos de gripes disseminados pelo mundo nas últimas décadas por exemplo. Trata-se de uma questão de saúde global. Como a grande maioria da população mundial se encontram nas cidades em profunda e complexa inserção com o urbano, mesmo as camadas mais isoladas do urbanismo como as chamadas comunidades tradicionais usam a cidade para seus afazeres e as ações necessárias para a própria reprodução do espaço e da vida. Atualmente a mobilidade social é muito maior que em outros tempos de pandemia e o mundo está agora mais globalizado do que nunca e os processos de espacialidade se ampliam a cada instante, o que facilita a expansão conjunta do vírus pelo planeta atingindo as localidades mais remotas do mundo.

Em se tratando das comunidades tradicionais, acompanhamos de perto a realidade das comunidades situadas nos quadrantes espaciais da zona costeira de Paraty, litoral sul fluminense no estado do Rio de Janeiro. Com o advento desse processo de globalização e dos processos de modernização, também esse conjunto de comunidades tradicionais vem tendo acesso cada vez maior ao processo de urbanidade e aglomerações sociais na cidade. Também vem crescendo gradativamente a presença desses sujeitos nas cidades e o número de viagens também já é bastante considerável tendo em vista o número de 
lanchas e barcos que chegam à cidade de Paraty diariamente configurando um verdadeiro mosaico de concentração urbana e mobilidade espacial dos sujeitos.

Segundo Sposito \& Guimarães (2020), "produzimos continuamente concentração e buscamos mobilidade" e nesse sentido o vírus possui muito mais condições de se distribuir espacialmente, no bojo da mobilidade urbana cada vez maior e mais frenética. Nessa perspectiva dos autores o vírus é capaz de saltar escalas geográficas e rapidamente se espalhar por todo o mundo com alto grau de transmissibilidade em função das aglomerações humanas em qualquer quadrante do planeta. Essa situação já atinge mais de 180 países de acordo com a veiculação das informações Organização Mundial de Saúde Nesse sentido, dadas as características da população mundial em termos de aglomerações é evidente que qualquer tipo de vírus se espalharia rapidamente entre os humanos como vem provando o aumento gradativo e de forma exponencial o número de infectados, de suspeitos de infecção e de óbitos que vem ocorrendo no mundo inteiro.

No Brasil também os números saltam aos olhos e a cada dia as notícias veiculadas expressam os altos índices de contaminação entre a população causando um verdadeiro pandemônio em meio a pandemia enquanto o vírus se espacializa cada vez mais. Assim, de acordo com as informações coletadas pelos epidemiologistas (OLIVEIRA,2020) as maiores distâncias que o vírus percorreu em pouquíssimo tempo atingindo milhares de pessoas em questão de dias se deu, principalmente por via aérea, favorecendo sua difusão pelos mais distantes continentes do planeta. Dessa forma, no Brasil as informações indicam que o vírus entrou por São Paulo e a partir daí se espalhou por todo o país de forma muito rápida, dadas as notícias veiculadas nos grandes meios televisivos e mídias alternativas além das inúmeras e rápidas análises difundidas em pequenas notas informativas de autores diversos.

De acordo com as referências oficiais do Ministério da Saúde, a primeira vítima do COVID-19 no Brasil (OLIVEIRA, 2020) aponta para o mês de fevereiro de 2020, praticamente três meses depois do surto - a princípio - se iniciar na China e de acordo com a nota técnica ENSP/Fiocruz, uma das grandes preocupações no enfrentamento da COVID-19 tem sido a disponibilidade de estrutura hospitalar capaz de atender a cerca de $20 \%$ de casos que requerem cuidados mais complexos. Mais especificamente, aproximadamente $5 \%$ exigem cuidados intensivos em unidades de saúde com capacidade de oferta de atendimento de alta complexidade (ENSP/Fiocruz, 2020, p. 3). A nota técnica destaca ainda que para dar conta da COVID-19, leitos e equipamentos já estão sendo adicionados à estrutura hospitalar de diversos municípios do país, sendo tais recursos muito importantes para mitigar problemas na capacidade de provisão de cuidados a pacientes e reduzir índices de letalidade da doença. Entretanto, frente a um quadro epidêmico já instalado, é fundamental monitorar a elevada probabilidade de que a demanda pelos recursos disponíveis cresça de forma exponencial e com padrões de uso prolongados.

As medidas preventivas estabelecidas pela Organização Mundial de Saúde no enfrentamento do vírus, dadas as variáveis que envolvem seu surgimento e a dificuldade de respostas rápidas do sistema científico e de saúde mundial frente a pandemias desse tipo, requerem o isolamento social das famílias e em particular dos sujeitos infectados ou com suspeitas de infecção pelo vírus. No entanto, enquanto o vírus dizimava populações na Europa e Ásia, os demais países, incluindo o Brasil, parece que não se prepararam de forma adequada para receber os primeiros casos de contaminação, o que vem causando grande número de infectados na ausência ou ineficiência das políticas públicas.

A demora em se estabelecer normas, formas e padrões de enfrentamento ao vírus que se aproxima de forma rápida e silenciosa pode incorrer novamente em ações tardias de combate a pandemia como os exemplos vividos na Itália, Espanha e EUA, de modo 
que mesmo o tesouro nacional emitindo dinheiro na forma de assistencialismo ou de tentativa de salvar parte da economia como desejam os grupos imperialistas do poder capitalista vão conseguir surtir o efeito desejado, resultando em grande número de vítimas da pandemia em curso e um desastre anunciado na economia do país. Nas análises de Escobar (2020),

\begin{abstract}
Nem mesmo trilhões de dólares chovendo do céu por um ato de misericórdia divina do Fed foram capazes de curar a COVID-19. Os "líderes" do G-7 tiveram que recorrer a uma videoconferência para perceber como eles não tem noção - mesmo quando a luta da China contra o coronavírus deu ao Ocidente uma trégua de várias semanas (ESCOBAR, 2020, s/p.).
\end{abstract}

Ressalte-se que nesse caso, "tempo, na verdade, é um elemento de altíssimo valor nas estratégias de combate à COVID-19" como indica estudos do Departamento de História da UFRRJ ${ }^{13}$. A perda de tempo dos demais países com certeza vai culminar em maiores desastres e colapso dos sistemas de saúde novamente. Embora essa trágica realidade continua estampada em todos os grandes veículos de notícias do mundo e destacados em diversas análises de especialistas no assunto, mesmo assim, com a notícia e as evidências de que o vírus se aproximava do país, os dirigentes da maior nação da América Latina demoraram para iniciar os preparativos de controle e formas de combate da pandemia e consequentemente se repetiu rapidamente o aumento de transmissibilidade como nos demais países citados. O Brasil desde então vem enfrentando o auto grau de transmissão do vírus que atinge de forma contundente todos os estados do país e vai avançando cada vez mais para as áreas mais afastadas dos grandes centros devido ao processo de mobilidade dos sujeitos e a conectividade dos mercados e suas ramificações pelo espaço. Sobre esse aspecto, de acordo com Sposito \& Guimarães, isto significa que

\footnotetext{
“A circulação e a conectividade entre diferentes lugares têm peso tão importante como a localização territorial no processo de difusão espacial de fenômenos de todo o tipo, mostrando a pertinência da teoria de Milton Santos, para o qual o espaço é um conjunto indissociável de sistemas de ações e sistemas de objetos" (SPOSITO \& GUIMARÃES, 2020, s/p.)
}

Diante do exposto, cumpre apontar que esse conjunto indissociável de sistemas de ações e sistemas de objeto vem favorecendo a reinvenção e readaptação do capitalismo que assume variadas formas de apropriação e espoliação, culminando em alto grau de acumulação. Sua reprodução por todo o planeta vem causando gigantesca onda de exclusão social e empobrecimento da grande maioria da população mundial enquanto um pequeno e seleto grupo se beneficia desse processo de especulação financeira. Nesse momento, mundialmente se fala em colapso desse sistema capitalista e parece não haver ainda orientações precisas sobre como manter o processo de acumulação mantendo a humanidade em quarentena. Embora com o início da pandemia na China a retórica do mercado informava que não havia risco sistêmico, de acordo com Escobar (2020) essa informação era falsa.

O autor afirma que de acordo com suas fontes vindas de bancários de Nova Iorque, "o risco sistêmico se tornou muito mais grave em 2020 do que em 1979, 1987 ou 2008, devido ao enorme risco de que o mercado de derivativos de US\$ 1,5 trilhão entrasse em colapso (ESCOBAR, 2020, s/p.). Mesmo com a enxurrada de dólares que o Fed emitiu na tentativa de salvar o mercado financeiro e impedir a queda de bolsas de valores pelo mundo não funcionaram, pois, o risco de um colapso financeiro no mundo inteiro permanece. Assevera Escobar (2020) que 
Como disseram as fontes, a história nunca havia visto nada parecido com a intervenção do Fed por meio de sua eliminação pouco compreendida das exigências de reservas bancárias comerciais, desencadeando uma potencial expansão ilimitada de crédito para impedir uma implosão derivada decorrente de um colapso total de mercadorias e bolsas de valores e ações em todo o mundo (ESCOBAR, 2020, s/p.).

Apesar das análises geopolíticas e econômicas explicitadas, países como o Brasil estão prestes a repetirem o desastre que foi a tentativa de salvar o mercado financeiro e a economia do país na Itália por exemplo, colocando em risco a saúde de toda a população do país. Essa alternativa da Itália culminou em milhões de mortos, no colapso total do sistema de saúde e na falha de tentativa de minimizar os efeitos da pandemia sobre o país. Nem as pessoas, nem o mercado e nem a economia foram salvos. Todos sucumbiram ao avanço da pandemia. O resultado foi trágico e serviu de exemplo para o mundo inteiro. A alternativa até agora eficaz na contenção do avanço do vírus é o processo de quarentena das famílias e o isolamento social de todos de acordo com as sugestões do órgão Mundial de Saúde. Reforçando esses pressupostos, a nota técnica da ESPN/Fiocruz (2020) indica ainda que

\footnotetext{
“As medidas para minimizar a circulação de pessoas continuarão sendo fundamentais para diminuir os níveis de transmissão da COVID-19, atenuar a propagação acelerada do vírus, distribuir a demanda por atendimento no tempo e evitar colapso do sistema de saúde, mesmo sem desconsiderar que simultaneamente outras iniciativas de prevenção e tratamento sejam implementadas" (ESNP/Fiocruz, 2020, p. 7).
}

Diante de tudo isso o governo brasileiro ainda insiste em "remar" na contramão das sugestões a nível mundial sobre a necessidade de se cumprir o isolamento social e o processo de quarentena. Inúmeras análises, gráficos, tabelas, mapas e outra infinidade de informações veiculadas indicam que no mundo inteiro essas medidas são as mais eficazes nesse momento para evitar a propagação do vírus. No caso brasileiro, a falta de suporte técnico e estrutural do sistema de saúde para atender a demanda em caso de pandemia coloca em risco toda a população tendo em vista a forma como o vírus vem avançando pelo país. A nota técnica da ESNP/Fiocruz (2020) indicando a necessidade de unir o conjunto de profissionais da área da saúde no plano público e privado sob uma mesma regulação política e estratégica reforça a ideia de que "a possibilidade de regulação única dos recursos públicos e privados precisa ser considerada fortemente" (ESNP/Fiocruz, 2020, p. 7).

Assistimos a uma disputa política e de sentidos que precisamos compreender melhor e enquanto isso ocorre, as análises indicam que a multiplicação exponencial do número de contaminados das áreas com condições de vida mais precárias é apenas uma questão de tempo, ainda mais com a realidade de muitos lugares que estão flexibilizando a quarentena. Como a retórica da necessidade de mercado permanece na condução dos sistemas de ações e sistemas de objetos na forma como historicamente vem ocorrendo no mundo, nem todos os lugares/quadrantes/sujeitos estão de fato respeitando a necessária quarentena e isso vem aprofundando sobremaneira a vida desses sujeitos, principalmente os grupos sociais mais vulneráveis e invisibilizados do planeta.

Assim, no Brasil por exemplo, apenas algumas cidades e estados decidiram fechar suas fronteiras, talvez um pouco tarde demais também. As demais, temendo um colapso total no sistema econômico e seguindo à risca as posições do presidente da república acabam por ignorar a iminência da pandemia e se colocam a serviço do capital mais uma vez, ao mesmo tempo que correm o risco de desaparecerem da face da terra por escolha 
própria ou induzida, pois o número de óbitos continua subindo no mundo inteiro e no Brasil não está sendo diferente. As grandes metrópoles do país já sucumbiram ao vírus e o pandemônio da pandemia já revela inúmeros óbitos atribuídos ao novo coronavírus, o que deixa em estado de alerta o restante do país, principalmente daqueles dirigentes mais responsáveis que optaram pelo fechamento de suas fronteiras e dos serviços menos essenciais nesse momento de crise sanitária.

Minas Gerais, São Paulo e Rio de Janeiro viraram o epicentro da pandemia em meados de março, mas a partir de abril principalmente, Manaus e vários outros estados da federação já apontaram crescimento exponencial da pandemia em seus territórios. Os dados destacados da nota técnica da ESNP/Fiocruz (2020, p. 3) indicam que as maiores taxas de letalidade (óbitos/casos confirmados) se encontravam na região Sudeste $(5,5 \%)$, seguida do Nordeste $(4,2 \%)$, Norte $(3,3 \%)$ e Centro-Oeste e Sul $(2,1 \%)$. Sobre essa questão de cunho inegavelmente caótica, desoladora e pandêmica, julgamos necessário transcrever um trecho bastante relevante que explicita claramente como a expansão exponencial do vírus caminha para um quadro aterrador e ameaça se expandir para as áreas interioranas dos estados afetados. Da nota técnica da Fiocruz destacamos o que segue:

Considerando as fases epidêmicas (epidemia localizada, aceleração descontrolada, desaceleração e controle), o Ministério da Saúde informa que na maior parte dos municípios ocorre a transmissão localizada. No entanto, tendo como referência nacional a incidência de 4,3 casos por 10 mil habitantes, chamam a atenção os cenários do Distrito Federal (13,2/100 mil), e dos estados de São Paulo (9,7/100 mil), Ceará (6,8/100 mil), Rio de Janeiro (6,2/100 mil) e Amazonas (6,2/100 mil), que apresentam os maiores coeficientes. Nesses locais, parece iniciar-se a fase de aceleração descontrolada da epidemia, principalmente se considerar a provável subnotificação dos casos, em especial, dos assintomáticos ou com sintomas leves. Frente a este cenário, o Ministério da Saúde já vem apontando para a necessidade de atenção às cidades com grandes aglomerações, ampliação de leitos e estrutura de suporte ventilatório para pacientes. Também tem sido uma preocupação a insuficiente capacidade laboratorial pública no país, capaz de processar aproximadamente 6.700 testes por dia, quando se estima que seriam necessários 30 a 50 mil testes moleculares RT-PCR por dia para fase mais crítica da COVID-19. Somando-se a tudo isso, começa a despontar a relevância de se atentar para a interiorização da epidemia (ESNP/Fiocruz, 2020, p. 3-4).

Como se estabelece, os dados levantados pela ESNP/Fiocruz apontam o Distrito Federal despontando com os maiores índices de infectados, embora os dados mudam constantemente e cada vez mais outras áreas e estados da federação vão sendo apontados com novos casos de infecção pelo novo vírus. No caso do Rio de Janeiro o problema se concentrou inicialmente na zona mais central da cidade e de acordo com estudos do PPGIHD-UFRRJ (2020),

\footnotetext{
“[...] a COVID-19 na Região Metropolitana do Rio de Janeiro se concentra em áreas de melhor renda e maior acesso a serviços de saúde; o isolamento social razoavelmente efetivo da classe média carioca pode estar contribuindo para proporcionar um tempo precioso aos gestores públicos na preparação para enfrentar o pico da pandemia"
}

Apesar desse estudo revelar dados importantes sobre o espraiamento do vírus pelo estado, a cada dia as notificações vão também se revelando de forma crescente e os casos de infecção vão se espalhando gradualmente pela zona metropolitana. Como consequência dessa espacialização do vírus, hoje muitos focos do mesmo já chegam em 
comunidades mais distantes dos grandes centros comerciais do estado e atingem em cheio diversas cidades menores além daquelas mais populosas. Os governos locais também decidiram pelo fechamento de suas fronteiras, mas ao cabo de algumas controvérsias, visto que o governador do estado em clara disputa política com o atual dirigente do país vem já há alguns meses protagonizando um processo de disputas políticas e de sentidos em relação ao modus operandi, o que vem trazendo sérias consequências para o estado do Rio de Janeiro. Não nos alongaremos nessa questão política mais interna do estado, deixemos para outras análises de cunho mais iminente, pois estamos a tratar justamente da iminência de um pandemônio em meio a pandemia do vírus que se espalha rapidamente entre a população de todo o estado.

Assim, voltando às inferências sobre a tomada de decisão de alguns governos locais optando pela paralização de serviços e fechamento de fronteiras sob os auspícios de controvérsias, citamos o caso de Angra dos Reis que em meio ao avanço do vírus tomou a decisão de fechar as fronteiras principalmente depois que o vírus se instalou em Rezende. Logo depois os meios jornalísticos noticiaram o primeiro caso em Mangaratiba ainda em meados de março e a partir de Mangaratiba o vírus se aproximou de forma muito rápida até atingir Angra dos Reis, até então sem haver tido nenhum caso confirmado apesar do alto grau de interação e influência política e comercial com as cidades vizinhas como Paraty por exemplo. A proximidade desses núcleos populacionais favorece as trocas e a mobilidade dos sujeitos, a circulação de mercadorias e realização de serviços, porém, nesses tempos de pandemia essa proximidade e os processos de interação social e comercial favorecem sobremaneira também a difusão do vírus.

Cumpre apontar que essa difusão do vírus está relacionada a grande amplitude de interação entre essas localidades, o que não difere do Brasil em termos mais gerais. Sobre essa questão, Sposito \& Guimarães (2020) inferem que "os dados sobre a difusão da doença no país indicam que se trata de um modelo hierárquico, fortemente relacionado com as interações espaciais existentes na rede urbana brasileira. Como frisamos, esse processo de interação faz parte da realidade de Angra dos Reis e Paraty, esta última com grande potencial turístico e que recebe grande porte de turistas que chegam diariamente de todos os quadrantes do planeta. A economia destas duas cidades gira em função do turismo, principalmente Paraty. Mas destacamos que Angra é importante ponto de passagem de turistas que chegam do grande Rio e de alguma forma também movimenta a economia da cidade. Nesse processo de interação, a conectividade entre as duas cidades é muito forte e esse vínculo favoreceu a passagem do vírus de Angra dos Reis para Paraty como acreditam todos.

Embora não se sabe ao certo de onde pode ter vindo primeiramente, o fato é que o vírus atingiu a cidade do Rio de Janeiro e já se instalou em Paraty. Assim, a disseminação do vírus em Paraty e os impactos da pandemia nas comunidades tradicionais da zona costeira de Cajaíba já são iminentes como veremos adiante. Essas áreas mais distantes dos centros comerciais, tidas como zonas mais interiorizadas do estado não possuem nenhum tipo de infraestrutura para o combate ao novo coronavírus, o que vem trazendo preocupações a todos os habitantes. A nota técnica da ESNP/Fiocruz (2020, p. 3) já alertava para a preocupação do vírus atingir essas áreas mais remotas e interiorizadas quando apresentou nos destaques que "um alerta deve ser acendido sobre a tendência que já se observa de interiorização da pandemia, que requererá novos arranjos e a necessidade de geração de capacidade de prestação de cuidados em condições mais adversas".

De acordo com os destaques e a realidade em que se encontram as cidades de Angra dos Reis e Paraty, sua conectividade e inter-relação comercial e turística, era de se esperar que em algum momento o vírus chegaria a esses quadrantes mesmo depois de 
tomadas as decisões de fechamento de suas fronteiras, o que não ocorreu de forma antecipada e mesmo após a decisão, os moradores continuaram a circular entre as duas cidades, o que provavelmente facilitou a disseminação do vírus.

\section{A disseminação do vírus em Paraty e os impactos da pandemia nas comunidades tradicionais da zona costeira de Cajaíba}

Assim, os atributos de cunho econômico acabam por caracterizar as duas cidades como rota de turismo e eixo de trocas comerciais e de serviços, mas devido ao fato do novo coronavírus encontrar maior facilidade de se expandir justamente em função dessa conectividade, a decisão correta a ser tomada seria pelo fechamento de suas fronteiras o mais rápido possível. Dadas as prioridades proeminentes de fechamento de fronteiras nesse meio tempo, Paraty e Angra dos Reis já haviam decidido pelo fechamento de suas fronteiras, mas parece que houve certa demora na decisão e mesmo após a tomada de decisão, parece que houveram alguns contrapontos entre os dois governos, segundo o que relataram alguns moradores das duas localidades.

Versaram essas pessoas que Angra dos Reis já havia decretado o fechamento das fronteiras e determinado o encerramento dos trajetos realizados pelos ônibus rodoviários que faziam as linhas São Paulo-Paraty-Angra e Paraty-Angra-Niterói, mesmo antes da notícia se espalhar que em Mangaratiba já havia um caso confirmado de infecção pelo novo vírus em meados de março de 2020. Paraty também havia determinado o fechamento das fronteiras, mas aí nesse ponto parece ter havido os contrapontos entre as duas cidades enquanto o vírus avançava.

O prefeito de Paraty tomou decisões severas sobre a continuidade de serviços turísticos determinando o fechamento das pousadas, a proibição das mesmas de receber novos turistas, o fechamento dos comércios ditos não essenciais, posteriormente o fechamento do cais de turismo e do encerramento das linhas de ônibus interestaduais (Paraty-Ubatuba) e intermunicipais (Paraty-Angra-Niterói), no entanto, os moradores informaram que essa decisão se deu por conta do prefeito de Angra que em tom de grave ameaça informou ao prefeito de Paraty que se este não tomasse a decisão correta de fechar suas fronteiras o mais rápido possível, o vírus começaria a se espalhar por Paraty. E como a cidade não conta com infraestrutura suficiente para receber os pacientes infectados, estes teriam que ser levados para Angra, mas a prefeitura de Angra não permitiria que estes pacientes infectados fossem recebidos e ocupassem os leitos já disponibilizados para os habitantes da cidade de Angra.

Após essa discussão entre os prefeitos é que Paraty decidiu fechar de fato suas fronteiras segundo o que apuramos das conversas no cais de pesca de Paraty. No entanto, o fechamento das fronteiras não necessariamente culminou no isolamento social das pessoas, pois percebeu-se em Paraty que, embora os comércios todos foram fechados com exceção das drogarias e rede de supermercados -, as linhas de ônibus de ligação com São Paulo e Rio de Janeiro foram encerradas e que nos trechos da Rio-Santos que corta Paraty a polícia estava controlando quem passava, ficou decidido que os moradores poderiam circular livremente entre Angra e Paraty, o que veio ocorrendo até então.

Com a proliferação do vírus em Angra dos Reis já era esperado que em algum momento o vírus chegaria em Paraty, o que ocorreu no início de abril. Após o primeiro caso confirmado de coronavírus a população ainda estava pelas ruas de Paraty circulando livremente e alguns pequenos comércios já haviam reabertos suas portas novamente de forma bastante tímida, mas estavam funcionando. Essa rápida reabertura de alguns comércios se deu pela visível flexibilização da quarentena. No entanto, nos últimos dias 
os casos de infecção pelo vírus aumentaram e chegaram a cinco casos confirmados segundo os relatos das pessoas e a divulgação no jornal local.

Rapidamente os pequenos comércios voltaram a fechar suas portas e já é possível observar alguns moradores usando máscaras pela cidade e nos comércios essenciais como drogarias e supermercados. Nesse ínterim o prefeito de Paraty decidiu fechar de vez o cais de turismo e o cais de pescadores, mas permitindo ainda alguns descarregamentos de peixes vindos de algumas comunidades da zona costeira e a continuidade de alguns serviços como a venda de gás e gelo no cais de pescadores. As comunidades costeiras também têm livre acesso ao cais para poder realizar compras nos supermercados e realizar serviços bancários.

A partir do dia 17 de abril as coisas começaram a ficar mais confusas e em clima de pandemônio após a divulgação do primeiro óbito em função do novo coronavírus. Segundo as informações do jornal local um senhor de 59 anos foi a óbito após ter sido infectado pelo vírus. Dos cinco casos confirmados de infecção, esse senhor era um deles. Como o comércio em geral na cidade está de portas fechadas, o movimento de pessoas pelas ruas teve grande diminuição e além disso a polícia não permite que os cidadãos circulem a noite pela cidade, diminuindo assim as possibilidades de propagação do vírus em meio a pequenas aglomerações. Alheios a tudo isso os habitantes das comunidades das costeiras que já vivem isoladas naturalmente devido ao quadrante espacial em que se encontram e tem historicamente grandes dificuldades de acesso à cidade, passaram a viver dias de incertezas diante do quadro aterrador da difusão do vírus em Paraty.

Essas comunidades ao longo dos últimos vinte (20) anos pelo menos passaram a depender em grande parte da cidade de Paraty e num momento de grande amplitude de uma pandemia mundial, se viram em uma situação inusitada e inesperada, pois já tinham dificuldades de acesso à cidade, mesmo com o advento da modernização e o processo de aquisição de embarcações a motor, principalmente as lanchas que começaram a serem adquiridas a partir de 2013/14 como relataram os primeiros proprietários de lanchas no Calhaus, uma das comunidades tradicionais de Cajaíba. Com a situação de pandemia que se instalou em Paraty os moradores desses quadrantes são os mais atingidos pela falta de serviços em seus lugares de origem e como a travessia pelo mar exige certos cuidados e depende das nuances da natureza, essas comunidades isoladas tiram seu sustento principalmente do mar, muito raramente das roças caiçaras e os demais serviços e produtos dependem da cidade, o que exige no processo de aquisição dos produtos a forma dinheiro, diferente das formas pretéritas de trocas.

Mas, em tempos de pandemia e do pandemônio que vem se tornando Paraty, essas comunidades mais uma vez terão que se reinventar para superar essa crise sanitária em seus lugares. São, portanto, as comunidades mais vulneráveis por não possuírem em seus lugares o mínimo de infraestrutura para combater tal problema iminente, embora a maior concentração de recursos nas regiões Sul e Sudeste do país.

Vale ressaltar que as comunidades da Cajaíba ficam em área periférica de Paraty, lugar de difícil acesso, somente via embarcação. Sendo cerca de 20 minutos deslocandode da praia de Paraty-Mirim e cerca de 90 a 120 minutos saindo do porto do centro de Paraty. 
Figura 1. Trajeto entre centro do Paraty e Praia Grande da Cajaíba.

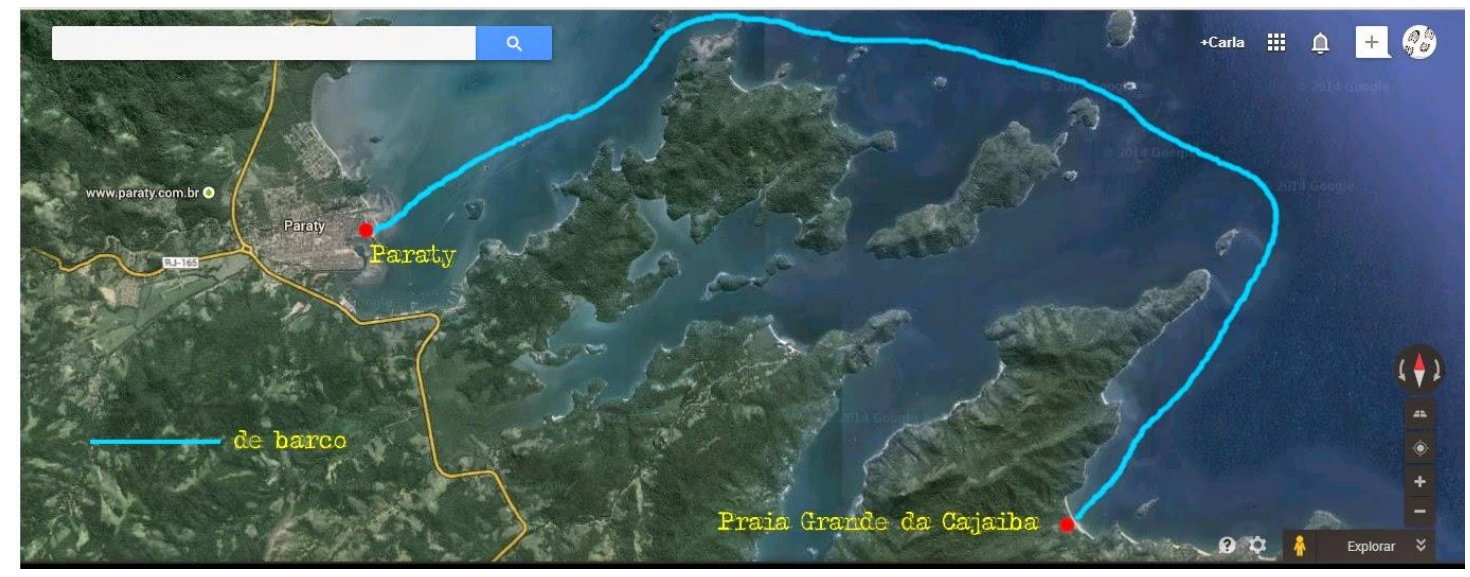

Fonte: Expedição Andando por aí. http://www.expedicaoandandoporai.com/2014/04/cachoeira-na-praia-grande-da-cajaiba-e.html

Figura 2. Referência da ponta e da enseada da Cajaíba em relação a Paraty Mirim e Mamaguaba. Pontos de localização de comunidades caiçaras

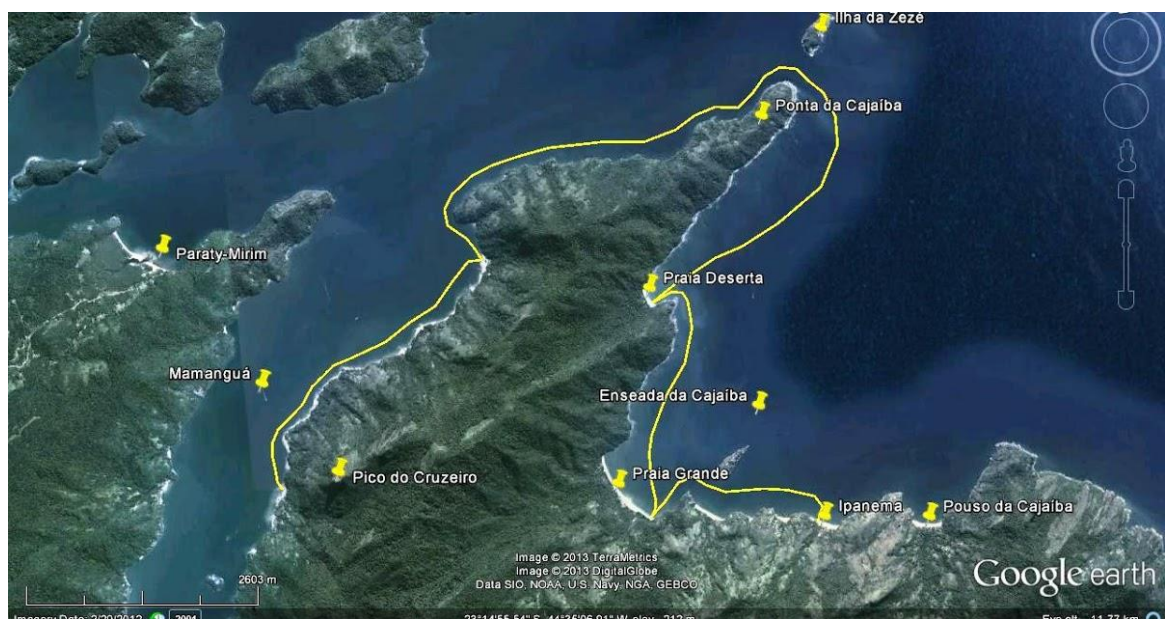

Fonte: YGARAPOA. Enseada da Cajaíba e retorno e Paraty-Mirim. http://ygarapoa.blogspot.com/2013/07/emseada-da-cajaiba-eretorno-paraty.html

Assim, devido a distância e dificuldades de acesso das comunidades de Cajaíba e devido às conjecturas referentes ao sistema de saúde das áreas cuja opacidade são bastante visíveis, uma maior atenção deveria ser dada ao conjunto de habitantes das áreas interiorizadas e no caso de nosso recorte analítico, as comunidades tradicionais costeiras de Cajaíba correm sérios riscos de permanecerem invisibilizadas desse processo de atendimento. Embora possuem acesso aos meios televisivos, nota-se que necessitam de maiores orientações de como proceder corretamente em casos de infecção pelo vírus. No entanto, aferimos que durante o processo de isolamento social nas comunidades caiçaras de Cajaíba em função da pandemia de coronavírus, a enfermeira da comunidade do Pouso da Cajaíba, responsável pelo atendimento no posto médico da comunidade do Calhaus e do Pouso, percorreu as demais comunidades para aplicar a dose de vacina contra a gripe nos mais velhos e nas crianças que ainda não haviam se vacinado e passou a dar instruções de higiene no sentido de evitar a contaminação com o vírus.

Nesse período nem o médico - que costuma vir até as comunidades de quinze (15) em quinze dias - veio até as comunidades, pois o cais de Paraty permaneceu fechado e circunscrito apenas à movimentação bastante reduzida de moradores locais, estes para 
chegarem até as redes de supermercados da cidade e às drogarias quando necessário além da livre circulação dos pescadores para o descarregamento do pescado. Os demais serviços permaneceram todos fechados a partir das primeiras notícias que "varreram" o país anunciando o surto de coronavírus. Nem as linhas municipais de ônibus circularam entre os bairros mais distantes, apenas pelos bairros próximos do centro sendo a linha mais longa a que liga Paraty a Trindade e Paraty a Angra dos Reis que foram "cortadas". Além disso, até as linhas interestaduais também foram encerradas.

Em Paraty o vírus foi detectado como o primeiro caso suspeito no início de abril e segundo as informações então circulando nas redes sociais e no cais de pesca, a pessoa infectada seria um agente da saúde pública que já havia sido medicado e se encontrava em casa na quarentena obrigatória. No entanto, poucos dias depois surgiram novas notícias de suspeitos e mais uma vez aumentaram as tensões entre as pessoas e dessa vez foi possível notar muitas pessoas andando de máscaras nas ruas e em alguns estabelecimentos comerciais até então em funcionamento devido ao relaxamento da quarentena nas últimas semanas.

O primeiro caso de morte em Paraty atribuído ao novo coronavírus se deu no dia 17/04/2020. Os habitantes da zona costeira se mostraram ainda mais apreensivos com essa notícia, pois vem lidando com a aproximação do vírus a cada dia. A espacialidade do vírus e os impactos na área da saúde e na segurança alimentar das comunidades tradicionais de Cajaíba se tornam cada vez mais iminentes, dadas a realidade precária do sistema de saúde na cidade e a falta de infraestrutura para atendimento do público em caso de maior disseminação do vírus. Importante se faz destacar alguns indicativos da presença do vírus em Paraty possivelmente vindo se instalando na região a partir de Mangaratiba como atribuem os moradores. Mas essa atribuição não necessariamente se revela como única possibilidade de espacialização do vírus, o que pode ter ocorrido tendo origem em outras paragens que não Mangaratiba.

\section{A espacialidade do vírus e os impactos na área da saúde e na segurança alimentar das comunidades tradicionais de Cajaíba}

Seguindo a espacialidade do vírus na Costa Verde do litoral sul fluminense, primeiro foi noticiado em meados de março o surgimento de uma pessoa infectada em Mangaratiba. Uma semana depois Angra dos Reis apresentou um quadro drástico de suspeitos que logo se tornaram casos confirmados de infectados, o que criou um campo fértil à difusão do vírus pela cidade em função de sua própria espacialidade e mobilidade urbana aumentando desde então o número de suspeitos ultrapassando a casa dos cem (100) suspeitos. Assinale-se, por oportuno, que por mais que medidas drásticas sejam tomadas por parte dos órgãos públicos culminando com o fechamento de suas fronteiras e encerramento da circulação dos ônibus intraurbanos, ainda assim está havendo circulação de pessoas pela cidade, o que facilita a difusão do vírus. Também foram anunciadas em Paraty medidas de proteção e implementação de políticas de inclusão das famílias mais vulneráveis como veremos adiante. Resta saber se essas políticas chegarão também nas comunidades das costeiras onde as condições de cunho social das famílias são péssimas e ainda tem que conviver com a nova ameaça que vem avançando sobre elas.

Nesse sentido, as comunidades das costeiras vêm sofrendo tensões com os impulsos urbanos de Paraty e Angra dos Reis, pois alguns barcos de Angra continuam pescando na Enseada da Cajaíba assim como outras embarcações maiores de fora do estado do Rio de Janeiro. Como muitos habitantes das costeiras ainda necessitam frequentar a cidade, de alguma forma está havendo contatos com esses grupos de 
moradores, pescadores e transeuntes da cidade, o que preocupa os demais moradores. Já admitem grande parte deles que o vírus vai chegar em suas comunidades em pouco espaço de tempo por mais que estejam evitando circular pela cidade ou manter contato com os sujeitos das embarcações de fora que pescam em Cajaíba.

Todos estão apreensivos com a chegada desse vírus em Paraty e se veem fadados a permanecerem isolados de tudo e de todos, no entanto, terão que se adaptarem ao novo processo de isolamento, considerando que atualmente, devido as políticas neoliberais e os impulsos metropolitano que também atingem esses pequenos redutos, essas comunidades, ao longo dos últimos trinta (30) anos vem sendo empurradas para o mundo do consumo nas cidades e foram obrigadas a abandonarem muito de suas práticas de vida ancestrais como o trabalho nas roças caiçara por exemplo. Dessa forma, passaram a depender cada vez mais da cidade e as trocas que se davam entre as pessoas sem a adição de dinheiro, agora necessitam cada vez mais do dinheiro para as transações. Em tempos de pandemia na cidade essas comunidades se veem cada vez mais acuadas em seus lugares sem muitas alternativas para sobreviver, além disso não são assistidas pelo poder público de forma mais ampla e inclusiva.

As políticas de distribuição de renda do governo federal não chegam a todos os moradores desses quadrantes espaciais mais afastados dos centros urbanos, justamente, sendo esses sujeitos por natureza espacial onde se encontram, os mais necessitados de se apropriarem dessas políticas. Embora muitas famílias estão cadastradas no Programa de Distribuição de renda do governo federal e recebem o Bolsa Família e um número ínfimo de pescadores artesanais recebem o seguro defeso do camarão pelo menos, a grande maioria não é assistida por esse ou outros programas e em meio a essa realidade vivida atualmente o quadro se torna cada vez mais caótico e uma reviravolta na vida dessas pessoas se torna cada vez mais iminente. Principalmente pelo fato de já terem diminuído drasticamente as atividades de pesca e a cada dia se aproximando o momento em que deverão encerrar o cotidiano da pesca artesanal, uma das principais atividades de renda dessas comunidades.

Como Paraty de forma forçosa teve que aderir ao processo de quarentena e isolamento social, a pesca artesanal não encontra outras formas de escoamento de sua já ínfima produção, senão pelo modo atual de descarregamento do pescado nas peixarias de Paraty ou pelas mãos dos atravessadores de plantão no cais de pescadores da cidade, o que causa uma sensação de desorientação/desordem social visto que dependem da pesca artesanal para sobreviverem. Diante desta realidade as famílias dispersas pela zona costeira já temem passar por sérias dificuldades financeiras, muito mais do que já passam historicamente como assevera Silva (2015), o que vem a incorrer no aprofundamento de sua invisibilidade social se políticas de cunho socioeconômica não forem implementadas com extrema urgência.

Afinal, de acordo com Silva (2015), no geral os trabalhadores da pesca artesanal “[...] estão em núcleos bastante dispersos, são mais numerosos e mais precarizados, produzem em pequena escala e usam pouca tecnologia pelo fato de terem maiores dificuldades de acesso aos direitos trabalhistas e às políticas públicas" (SILVA, 2015, p. 20). Em vista dessas dificuldades de acesso às políticas públicas que Silva (2015) infere, reiteramos a necessidade de implementação das políticas nas comunidades tradicionais de Cajaíba, pois a pandemia e o aviltamento no valor do pescado começa a desestabilizar a economia das famílias, aflorando as desordens (RIBEIRO, 2005) na própria conjuntura das sociabilidades dos sujeitos na escala da vida coletiva.

Em face das notícias indicando cada vez mais o avanço do vírus pelos quadrantes espaciais do país, os habitantes de Cajaíba temem pelo pior e tentam desesperadamente se proteger de formas de contágio decidindo pelo auto isolamento das famílias embora 
muitos outros ainda não assimilaram a dimensão do perigo de contaminação. Mesmo assim, há aqueles mais atentos ao problema que estão preocupados com os seus semelhantes e procuram informar os seus sobre a fatalidade que esse vírus vem causando no mundo. De algumas narrativas destacamos que alguns sujeitos estão tentando se organizar para evitar que o vírus chegue até suas comunidades impedindo que pessoas de fora adentrem as comunidades, estas muito vulneráveis historicamente, pois não possuem infraestrutura adequada para o enfrentamento de uma crise de saúde global como essa. Indicam esses sujeitos que "simplesmente não podemos esperar e deixar essa doença causar estragos em nossas comunidades".

Para tentar assegurar que não haja a proliferação do vírus nas comunidades, estas tentam desesperadamente impor algum tipo de isolamento, de modo que se evitem até mesmo a circulação entre as demais comunidades. Praticamente todos os bares e restaurantes situados nessas comunidades foram fechados e paralisaram seu comércio, já muito ínfimo em baixa temporada. No entanto, a necessidade de usufruto da cidade de Paraty para aquisição de alimentação e produtos essenciais às famílias, a circulação pelo mar, embora de forma bastante reduzida, continua a ocorrer, o que traz maiores preocupações para as famílias que não necessitam sair tanto, pois estas ainda conseguem algum sustento das pequenas roças caiçaras que mantém em seus quintais. Nesse caso, independentemente de crises de qualquer natureza, destacamos das narrativas caiçaras e das diversas oportunidades de relatos orais dos sujeitos que as famílias possuem uma relação com a terra que permite a manutenção de práticas ancestrais de solidariedade e sociabilidade entre todos. E mesmo que nem todas as famílias estejam envolvidas com seus roçados, as que ainda mantém essa prática contribuem com a distribuição dos alimentos produzidos para as demais famílias.

Além das narrativas e da história oral dos sujeitos indicarem tais ações, durante a escrita deste ensaio também presenciamos na comunidade do Calhaus tais atitudes de sociabilidade e solidariedade orgânica entre os sujeitos da ação. Do mesmo modo, nessas comunidades em relação a pesca, diariamente os sujeitos que trabalham no mar trazem para terra parte de sua produção pesqueira justamente para distribuir entre a comunidade e as famílias mais necessitadas que por ventura possam não possuir os meios necessários para a realização da pesca. Também ocorre que quando algum morador solicita que o pescador ao visitar o cerco traga algum peixe para ele, esse pedido é atendido prontamente e quando a visita ao cerco - que ocorre em geral duas vezes durante o dia - não rende peixe algum, os pescadores vão até seus barcos onde mantém o peixe no gelo e retiram o necessário para o sujeito que fez o pedido.

Nessa perspectiva, cumpre apontar que esses modos de vida extrapolam a dimensão da produção do espaço que segundo Silva (2015), é regulado por diversas formas. Como averba a autora, a "geografia das existências" se propõe a uma leitura e compreensão dessa dinâmica da produção do espaço na perspectiva dos sujeitos, seus costumes e tradições culturais ancestrais que se inserem na produção do cotidiano e do lugar vivido e praticado. Infere Silva (2015) que

As geografias das existências fazem referência à produção do cotidiano e do lugar, tecidas nas relações de trabalho, nos vínculos sociais, nas sociabilidades e heranças culturais que marcam o pescador no exercício de sua função, mas também no ócio e no convívio com amigos e familiares: possui uma espacialidade (relação com os objetos) e historicidade (relação com as heranças culturais, as memórias e identidades coletivas, marcado por normas tecidas nos costumes - direito consuetudinário, que são normas construídas a partir dos costumes e tradições de atos e valores de um grupo - e que tem a oralidade como um dos princípios de linguagens mais importantes) (SILVA, 2015, p. 20-21) 
Como assevera a autora, os vínculos sociais e as relações de sociabilidades marcam as dinâmicas da vida coletiva dos sujeitos e assim como as geograficidades (Dardel, 2011) se dão como construções cotidianas do espaço vivido e concebido, também as geografias das existências (SILVA, 2015) conformam as práticas e sentidos da ação que por sua vez conformam a vida coletiva e as sociabilidades tecidas no lugar. Nesse ambiente vivido pelos sujeitos as existencialidades subjetivas e o movimento do mundo no tempo e no espaço marcam o processo de solidariedade e sociabilidade existente nas comunidades onde cada sujeito tem a sua importância no papel central que a comunidade exerce na produção social do espaço.

Portanto, a relação dos sujeitos com o ambiente vivido configura, na concepção humanística de Dardel (2011), a geograficidade desses sujeitos. Geograficidade é, portanto, um termo que compreende todos os tipos de ligações e inter-relações entre o homem e os ambientes vividos anterior à análise e à atribuição de conceitos a essas experiências, de acordo com as análises de Dardel (2011). E relacionado às geograficidades temos as historicidades dos sujeitos que se dão pela relação com as heranças culturais, as memórias e identidades coletivas, marcado por normas tecidas nos costumes como indica Silva (2015, p. 21) e que dá sentido à sua cultura, a relação com o espaço, com a natureza, a roça, a pesca, o extrativismo, a produção de embarcações, as redes de pesca, os usos do lugar, do espaço, do território.

A roça e a pesca artesanal, portanto, são atributos culturais de extrema importância e referência existencial dos sujeitos, mas que vem sofrendo intervenções verticais que trazem a desordem ao lugar na concepção de Ribeiro (2005). Em tempos de pandemia as desordens atingem outros patamares que somados às normas e ordens que vem de fora culminam em maior grau de desordem nesses lugares. A importância do cultivo de alimentos em meio a pandemia começa a tomar uma dimensão bastante elucidativa em termos das desordens causadas a essa cultura. Parece estar havendo um certo resgate dessa cultura, embora algumas famílias nunca abandonaram tais práticas.

Sobre essa questão destacamos algumas falas pertinentes que nos ajudam a refletir sobre a importância do roçado caiçara, prática ancestral do legado indígena que foi cultuada em grande medida até alguns anos atrás, impedida de continuar sendo exercida em função de determinações instituídas pelos órgãos ambientais, principalmente a partir da década de 1990. Com a proibição das atividades de grandes roçados, os habitantes cada vez mais tiveram que se readaptarem às atividades de pesca. Assim, em Cajaíba a pesca artesanal vem tomando grande vulto à medida que as famílias vão aderindo a praticamente ao único meio de subsistência. Cumpre destacar que se mantendo as possibilidades de escoamento da pequena produção pesqueira, as famílias mesmo com muita dificuldade vão se mantendo. Porém, com o advento do novo vírus e a necessidade de permanecer em quarentena, o que de certa forma alivia algumas famílias é que ainda se tem a pesca e por mais que tenha acabado as atividades de grandes roçados, tem muita banana, tem as frutas e legumes que ainda são cultivados em alguns quintais.

Com a ameaça do vírus permanecer infectando as pessoas por tempo indeterminado, é possível que esteja havendo já um certo resgate ancestral da coleta e da agricultura caiçara. Em um dos grupos de moradores das comunidades tradicionais (por meio de WhatsApp) resgatamos a seguinte informação: na Juréia, litoral sul de São Paulo os moradores das comunidades tradicionais entraram com um pedido na Secretaria de Meio Ambiente solicitando autorização de abertura de novas roças e parece que esse processo todo de quarentena está servindo para valorizar as coisas que eles têm lá. Mas isso as famílias das costeiras, pois quem está nas cidades, com certeza a situação é totalmente diferente como podemos atestar em dois áudios que recebemos de duas moradoras da comunidade do Pouso da Cajaíba e da comunidade da Praia Grande da 
Cajaíba respectivamente, onde as famílias estão se beneficiando da colheita dos produtos que ainda são cultivados em suas roças caiçaras que mesmo de pequeno porte está servindo para aliviar a tensão e preocupação de faltar alimentos para as famílias em tempos de pandemia e isolamento social.

Assim, algumas famílias que mantiveram seus pequenos roçados contrariando as normas impostas pelo órgão ambiental tiram proveito de suas plantações de alimentos sem adição de qualquer tipo de agrotóxico e complementam sua alimentação com os frutos da terra cultivados por eles próprios.

\footnotetext{
“Aqui a gente está comendo também abacate, fruta pão, banana, coquinho palmito que é daquele que faz quando maduro, faz o açaí, a gente no quintal lá embaixo tem... a gente está comendo os coquinhos, é, deixa eu ver o que mais, é isso mesmo, tem que estar aproveitando, tem que ser o que tem por aqui também, entendeu? Até passar essa fase aí” (Maria do Pouso da Cajaíba).

“Aqui está tudo bem, graças a Deus. É, assim meio preocupados com esse vírus aí, né! A gente está presa também, está aqui, mas graças a Deus aqui a gente tem liberdade, a gente vai na roça e mexe com a terra, né! Aí vocês aí na cidade têm que ficar presos dentro de casa (Yolanda da Praia Grande da Cajaíba).
}

As roças desde a muitos anos foram proibidas de continuarem existindo e hoje pouquíssimas pessoas ainda mantém um roçado de fundo de quintal, o que não supre as necessidades das famílias que dependem do grosso produzido em outros lugares, assim como dependem das normas de organização social definidas em outros lugares, longe de sua vida cotidiana. Como a pesca vem parando sucessivamente em função da pandemia, as famílias já sentem o aprofundamento da crise alimentar e cada vez mais acuados em seus lugares não tem perspectivas de melhoras nesse quadro de crise sanitária planetária. De alguma forma seus lugares estão conectados com o mundo, mas as decisões tomadas em outros lugares estranhos a esses sujeitos não chegam nesses lugares de forma benéfica a todos. Ao mesmo tempo em que vivem conectados com o mundo através da circulação massiva de informações e interações com os produtos eletrônicos que se tornaram febre mundial, vivem o isolamento desse mundo, inclusive excluídos dos serviços produzidos nesse mundo estranho a eles.

As decisões vêm de fora, as normas de vida foram determinadas fora de suas realidades cotidianas e eles não foram convidados a opinarem sobre essas normas ou decisões. Sendo tais decisões a serem tomadas em suas comunidades com certeza os encaminhamentos seriam tomados por todos com decisões e normas criadas e averbadas dentro das comunidades de forma horizontal e não vindas de fora de forma vertical. Queremos dizer com isso que os modos de vida e as tomadas de decisões nessas comunidades ainda seguem um padrão de solidariedade e sentido comunitário onde os sujeitos ainda se ajudam e em tempos difíceis as famílias se preocupam umas com as outras.

Nesse sentido, as sociabilidades cumprem um importante papel orientando as ações dos sujeitos para a solidariedade e cooperação mútua, diferente das orientações mercadológicas que culminam com a competitividade e falso empreendedorismo a qualquer custo. Entre essas duas realidades distintas afloram as disputas de sentidos. As dinâmicas de vida cotidiana nessas comunidades são inegavelmente muito diferentes dos modos de vida urbanos, ainda que nessas comunidades o urbano esteja presente nos novos modos de consumo e no aumento da circulação dos sujeitos nas cidades convivendo cada vez mais com o modus operandi urbano. Ainda assim seus modos de vida de caráter comunitário prevalecem sobre o urbanismo concreto. As relações com a natureza ainda são a base da vida nessas comunidades e de sua interação dependem as ações dos sujeitos no campo da reprodução do espaço. 
Apesar da dinâmica nos modos de vida dessas comunidades estabelecerem as bases sociais necessárias para a reprodução do espaço e da própria existencialidade dos sujeitos nesses lugares de culturas tradicionais, a invisibilidade dos sujeitos e de suas ações colocam em risco seu próprio modo de existência, visto os processos de expropriação de seus bens naturais, o aviltamento de seus produtos de subsistência e o aprofundamento de suas péssimas condições de vida. Sobre essa questão, Santos (2020) destaca que no mundo existem diversas zonas de invisibilidade que correspondem a situações de muita pobreza e falta de políticas públicas que venha a atender as demandas das populações, estas muito vulneráveis do ponto de vista de uma situação de pandemia como a atual enfrentada pelo mundo. Infere Santos (2020, p. 9) que "as zonas de invisibilidade poderão multiplicar-se em muitas outras regiões do mundo, e talvez mesmo aqui, bem perto de cada um de nós".

Não com essas palavras, mas em tom bastante assustador, Escobar (2020) indica que independentemente de sua origem, que ainda não está estabelecida de maneira conclusiva [...], a COVID-19 já coloca questões imensamente sérias sobre biopolítica e bioterrorismo sendo que a realidade do mundo está mudando a uma velocidade vertiginosa depois que Pequim identificou o coronavírus como um ataque de armas biológicas. Isso pode vir a causar uma reviravolta no mundo do poder econômico que pode culminar em maiores desigualdades sociais mundiais, dessa forma há grandes possibilidades de aumentar de forma drástica os espaços de invisibilidade pelo mundo. $\mathrm{O}$ cotidiano da vida individual e da vida coletiva dessas camadas mais invisibilizadas expõe o aprofundamento de uma crise sem precedentes enquanto na outra ponta os agentes econômicos cumprem seu papel de acumulação em detrimento de uma distribuição mais equitativa dos bens produzidos no mundo. São as formas de dominação, as disputas políticas e de sentidos que correspondem a esse processo destruidor da vida coletiva cotidiana e dos espaços de sociabilidades onde reside as geografias das existências. Para compreender a geografia das existências é fundamental compreender as formas de dominação e o exercício do poder no espaço geográfico marcado pelo capitalismo periférico (SILVA, 2015). Também é preciso compreender o sentido das ações dos sujeitos e seus modos de existência e reprodução social do espaço em meio ao caos que as grandes corporações distribuem pelos quadrantes espaciais do planeta.

Diante desse quadro aterrador, é preciso estar atento às aspirações e necessidades dos sujeitos comuns e compreender suas linguagens e inquietações perante um mundo em pânico, em verdadeiro pandemônio competitivo em nome de um capitalismo excludente e expropriatório metamorfoseado de globalização, modernidade e avanço tecnológico. Nem essas tecnologias e essa era globalizada é capaz de solucionar de vez o problema da pandemia cada vez mais iminente e destruidora da vida humana de forma invisível e inesperada. Hoje o mundo vive o pandemônio em pandemia e os sujeitos do mundo todo estão por enquanto condenados a se infeccionar em algum momento, pois o processo de mobilidade socioespacial continua sendo um campo fértil para a difusão/propagação do vírus e aumento sem precedentes da pandemia.

Além disso, as mercadorias ainda que de forma restrita, continuam circulando e junto com elas o vírus se propaga atingindo inóspitos lugares do planeta onde se situam diversas zonas de invisibilidade. Do outro lado, nas zonas de visibilidade ou luminosas como adverte Milton Santos (2017), a situação é ainda pior, pois se torna o espaço ideal para a propagação do vírus se considerarmos que as classes mais abastadas provavelmente foram os responsáveis pela rápida difusão do vírus pelo mundo, pois estas possuem condições mais favoráveis para realizar grandes, longas e várias viagens ao exterior atingindo os grandes centros de aglomerações urbanas pelo mundo tendo no turismo um dos grandes pontos difusores de vírus. A cidade de Paraty se enquadra nessa perspectiva 
por ser um dos principais locais onde a base do turismo faz parte da economia da cidade, o que a torna suscetível ao espraiamento do vírus. Nesse sentido, as medidas de proteção e implementação de políticas públicas de inclusão das famílias mais vulneráveis em Paraty diante da espacialização do novo coronavírus se faz necessário, considerando que uma grande gama de núcleos populacionais necessita serem assistidos em momento tão delicado.

Sendo Paraty considerada um polo turístico, a atração de grande contingente de pessoas faz com que haja aumento nas formas de aglomeração e somados a isso já ocorre esse processo de aglomeração devido ao fato de a cidade ser o centro de boa parte dos serviços buscados pelas populações de todos os quadrantes que a cidade abrange. Quanto maior as formas de aglomeração urbana e mobilidade social dessas localidades e de seus cidadãos, suas interconectividades e espacialização, maior e mais velozmente o vírus encontra brechas para se expandir. Essa situação caótica não foge à consciência dos povos e comunidades tradicionais nos mais distantes quadrantes espaciais e estes temem pela sua segurança alimentar e na área da saúde, visto que em seus lugares não há o mínimo de recursos ou estruturas de suporte para abrigo das pessoas que por ventura possam vir a serem infectadas pelo vírus.

\section{Considerações finais}

As especulações sobre a COVID-19 e a realidade dos lugares invisibilizados indicam a necessidade de uma nova leitura de mundo e compreensão dos dilemas que estão por vir, considerando as aglomerações urbanas, a mobilidade espacializada e o isolamento social necessário diante do alto grau de transmissibilidade do vírus. A disseminação do vírus em Paraty e os impactos da pandemia nas comunidades tradicionais da zona costeira de Cajaíba exigem outras/novas formas de intervenção que priorize o atendimento às famílias desassistidas do poder público e sem ou com pouco acesso a informações e ao usufruto de políticas inclusivas. As conjecturas e análises aqui esboçadas indicam que os grandes movimentos da sociedade amparados pelos discursos da modernidade conduzem as disputas societárias e, por conseguinte, as disputas de sentidos.

Mas em meio ao caos social então distribuídos pelos quadrantes espaciais se encontram diferentes formas de existências que conformam o espaço tendo nas sociabilidades dos sujeitos as bases de sua própria reprodução sócio espacial. No entanto, diante da atual crise sanitária mundial, a espacialidade do vírus e os impactos na área da saúde e na segurança alimentar das comunidades tradicionais de Cajaíba requerem maior atenção por parte do Estado. O problema é que as pessoas vivem em um sistema urbano intrinsecamente especializado, conectado e dependente do processo de mobilidade social, campos extremamente férteis à fácil difusão do vírus que vem acarretando prejuízos principalmente sociais às classes menos abastadas e a coletividade precisa enfrentar esse processo de forma mais unificada possível. Essa unificação deve orientar as políticas que deverão dar suporte às famílias mais vulneráveis.

Melhor será exercitar e buscar os meios mais adequados para a efetiva adoção de medidas de proteção e implementação de políticas públicas de inclusão das famílias mais vulneráveis em Paraty diante da espacialização do novo coronavírus. Essas políticas devem vir acompanhadas de medidas mais concretas e de forma mais prolongada no tempo e no espaço de modo que garantam a salvaguarda da saúde e inclusão da população em políticas de assistência nesses tempos sombrios de pandemia. Apesar das dificuldades enfrentadas cotidianamente, as formas de resistências dos sujeitos demonstram que é possível um mundo melhor onde todos possam superar juntos essas dificuldades e 
conjuntamente elaborar políticas que contemplem todas as classes e níveis sociais de vida. Mesmo com todo o discurso de modernidade e difusão de informação em cadeia global, os lugares mais invisibilizados, distantes dos grandes centros de aglomeração social e urbana mais uma vez nos trazem lições de vida que precisam ser levadas em consideração. Embora esses sujeitos em suas comunidades não se apropriam de todo o mote do processo de modernização e se veem obrigados a se reinventarem a cada dia, ainda assim seus modos de vida de caráter comunitário prevalecem sobre o urbanismo concreto. As relações com a natureza ainda são a base da vida nessas comunidades e de sua interação dependem as ações dos sujeitos no campo da reprodução do espaço. Quando tudo isso passar, que possamos ter um olhar diferente para com o outro. Que possamos ouvir mais e julgar menos. Afinal, "Somos ondas do mesmo mar, folhas da mesma árvore, flores do mesmo jardim”. Script chinês.

\section{Notas}

1 - Membro do Núcleo de Pesquisa e Extensão - Urbano, Território e Mudanças Contemporâneas - NUTEMC/FFP/UERJ. Bolsista CAPES. O presente trabalho foi realizado com apoio da Coordenação de Aperfeiçoamento de Pessoal de Nível Superior - CAPES.

2 - SPOSITO, Maria Encarnação Beltrão \& GUIMARÃES, Raul Borges. Por que a circulação de pessoas tem peso na difusão da pandemia. Notícias Unesp de 26/03/2020.

3 - PORTELA et al. Limites e possibilidades dos municípios brasileiros para o enfrentamento dos casos graves de COVID-19 - Nota Técnica. ENSP/Fiocruz, 2020.

4 - ESCOBAR, Pepe. China travou guerra híbrida com os EUA - Precipitação do surto de Covid-19 coloca Pequim e Washington em rota de colisão. Ásia Times, 2020.

In: https://asiatimes.com/2020/03/china-locked-in-hybrid-war-with-us/ Acesso em 12 de abril de 2020.

5 - YANG, Li. Carta aberta. Brasil 2 Pontos, reportagem de 03/04/2020.

6 - ANDERSEN, Kristian G.; RAMBAUT, Andrew; GARRY, Robert F. A origem proximal do SARS-CoV-2. Nature Medicine, $\mathrm{n}^{\circ}$. 26, 2020.

7 - SANTOS, Milton. A natureza do espaço: técnica e tempo-razão e emoção/ Milton Santos. - 4 ed. 9. Reimpr. - São Paulo: Editora da Universidade de São Paulo, 2017. - (Coleção Milton Santos; 1$)$.

8 - RIBEIRO, Ana Clara Torres. Sociabilidade hoje: leitura da experiência urbana. Caderno CRH, Salvador: UFBA, v. 18, nº 45, set-dez 2005, p. 411-412.

9 - DARDEL, Éric. O homem e a terra: natureza da realidade geográfica. Trad. Werther Holzer. São Paulo: Perspectiva, 2011.

10 - SAID, Abbul Mahmebb - SILVA, José Carlos da. A pesca geograficizando os lugares. Mares: Revista de Geografia e Etnociências, v. 1, no . 2, 2019.

11 - SILVA, Catia Antonia da. Política pública e território: passado e presente da efetivação de direitos dos pescadores artesanais no Brasil/ Catia Antonia da Silva. - 2 ed. - Rio de Janeiro: Consequência, 2015.

12 - SANTOS, Boaventura de Sousa. A cruel pedagogia do vírus. Coimbra: Edições Almedina, S.A, 2020.

13 - PPGIHD-UFRRJ - Dinâmica socioespacial da Covid-19 na cidade do Rio de Janeiro e na Baixada Fluminense, 2020.

Disponível em: https://www.ppgihd-open-lab.com/post/din\%C3\%A2mica-socioespacial-dacovid-19-na-cidade-do-rio-de-janeiro-e-na-baixada-fluminense Acesso em 25 de abril de 2020.

\section{Referências bibliográficas}

ALVES, José Eustáquio Diniz. A pandemia de coronavírus (COVID-19) e o pandemônio na economia internacional, in EcoDebate, ISSN 2446-9394, 9/03/2020. Disponível em: https://www.ecodebate.com.br/2020/03/09/a-pandemia-de-coronavirus-COVID-19-e-o- 
pandemonio-na-economia-internacional-artigo-de-jose-eustaquio-diniz-alves/. Acesso em 12 de abril de 2020.

ANDERSEN, Kristian G.; RAMBAUT, Andrew; GARRY, Robert F. A origem proximal do SARS-CoV-2. Nature Medicine, $n^{\circ}$. 26, 2020.

DARDEL, Éric. O homem e a terra: natureza da realidade geográfica. Trad. Werther Holzer. São Paulo: Perspectiva, 2011.

ESCOBAR, Pepe. China travou guerra híbrida com os EUA - Precipitação do surto de COVID-19 coloca Pequim e Washington em rota de colisão. Ásia Times, 2020. Disponível em: https://asiatimes.com/2020/03/china-locked-in-hybrid-war-with-us/ https://www.ppgihd-open-lab.com/post/din\%C3\%A2mica-socioespacial-da-COVID-19na-cidade-do-rio-de-janeiro-e-na-baixada-fluminense Acesso em 25 de abril de 2020.

OLIVEIRA, Wanderson Kleber de et. al. Como Brasil pode conter o COVID-19. Epidemiol. Serv. Saude, Brasília, 29(2):e2020044, 2020.

PORTELA et al. Limites e possibilidades dos municípios brasileiros para o enfrentamento dos casos graves de COVID-19 - Nota Técnica. ENSP/Fiocruz, 2020. PPGIHD-UFRRJ - Dinâmica socioespacial da COVID-19 na cidade do Rio de Janeiro e na Baixada Fluminense, 2020. Disponível em:

RIBEIRO, Ana Clara Torres. Sociabilidade hoje: leitura da experiência urbana. Caderno CRH, Salvador: UFBA, v. 18, nº. 45, set-dez 2005, p. 411-412.

SAID, Abbul Mahmebb - SILVA, José Carlos da. A pesca geograficizando os lugares. Mares: Revista de Geografia e Etnociências, v. 1, $\mathrm{n}^{\circ}$. 2, 2019.

SANTOS, Boaventura de Sousa. A cruel pedagogia do vírus. Coimbra: Edições Almedina, S.A, 2020.

SANTOS, Milton. A natureza do espaço: técnica e tempo-razão e emoção/ Milton Santos. - 4 ed. 9. Reimpr. - São Paulo: Editora da Universidade de São Paulo, 2017. (Coleção Milton Santos; 1).

SILVA, Catia Antonia da. Política pública e território: passado e presente da efetivação de direitos dos pescadores artesanais no Brasil/ Catia Antonia da Silva. - 2 ed. - Rio de Janeiro: Consequência, 2015.

SPOSITO, Maria Encarnação Beltrão \& GUIMARÃES, Raul Borges. Por que a circulação de pessoas tem peso na difusão da pandemia. Notícias Unesp de 26/03/2020.

YANG, Li. Carta aberta. Brasil 2 Pontos, reportagem de 03/04/2020. 